University of Michigan Law School

University of Michigan Law School Scholarship Repository

\title{
Public Access to Primary Legal Information in China: Challenges and Opportunities
}

\author{
Xiaomeng Zhang \\ University of Michigan Law School, zxm@umich.edu
}

Available at: https://repository.law.umich.edu/librarian/20

Follow this and additional works at: https://repository.law.umich.edu/librarian

Part of the Legal Writing and Research Commons, and the Library and Information Science Commons

\section{Recommended Citation}

Zhang, Xiaomeng. "Public Access to Primary Legal Information in China: Challenges and Opportunities." Legal Info. Mgmt. 14, no. 2 (2014): 132-42.

This Article is brought to you for free and open access by the Other Publication Series at University of Michigan Law School Scholarship Repository. It has been accepted for inclusion in Law Librarian Scholarship by an authorized administrator of University of Michigan Law School Scholarship Repository. For more information, please contact mlaw.repository@umich.edu. 


\section{INTERNATIONAL PERSPECTIVES}

\section{Public Access to Primary Legal Information in China: Challenges and Opportunities}

Abstract: Despite a lack of a national legislation that mandates open government information in the People's Republic of China, each major government branch has taken proactive efforts to make primary legal information issued within their power available to the public. A close examination of Chinese official legal information portals on the national level reveal issues such as a lack of uniformity and a lack of access to authenticated primary legal information. This article, by Xiaomeng Zhang ${ }^{1}$, proposes a solution that would not only offer more consistent guidelines for the government but would empower the public to assert their right to primary legal information more powerfully and effectively.

Keywords: legal sources; legal research; public access; People's Republic of China

\section{INTRODUCTION}

The People's Republic of China's (China) official attempt to promote public access to government information, including legal information, started in the 1990s. The Guangzhou City government issued the very first municipal regulation on publicising 
government affairs to the public in $1992 .^{2}$ It was 15 years later that the first nation-wide regulation, Regulation of the People's Republic of China on the Disclosure of Government Information ("OGl"), was enacted. ${ }^{3}$

This article intends to explore and evaluate China's still-evolving legal framework of public access to primary legal information on the national level. I will start with a panoramic review of the current legal regime in section $\mathrm{II}$, followed by an evaluation of the Chinese government's efforts to provide access to primary legal information in legislative, judicial and executive branches in Section III. I will conclude with recommendations for solutions to the lack of uniformity and lack of access to authenticated primary legal information revealed through the evaluation in Section III.

The focus of this article is on primary legal information, including official legal instruments such as laws, regulations, departmental rules, judicial opinions, interpretations, and other policy guidance as well as legal documents produced during the process of law making and rulemaking.

\section{THE CHINESE LEGAL FRAMEWORK ON PUBLIC ACCESS TO PRIMARY LEGAL INFORMATION}

\section{A. Overview of the Chinese Legal System and Primary Legal Information}

Under the current legal framework, there are four major branches of national governments in China: the National People's Congress ('NPC') and its Standing Committee ("NPCSC"), the State Council, the Supreme People's Court ('SPC"), and the Supreme People's Procuratorate ('SPP”).

Each branch exercises different functions and powers, as stipulated by the Chinese Constitution. As a result, each branch produces important primary legal information within its power and jurisdiction, including National Laws, Administrative Regulations, Judicial Decisions and Interpretations, Procuratorate Decisions and Interpretations as well as other rules and orders.

The Constitution is the fundamental law and has the supreme legal authority in China. "No laws or administrative or local regulations may contravene the Constitution". 5

National Laws are issued and amended by the NPC and/or its Standing Committee, promulgated by Order of the President, and signed by the President. ${ }^{6}$ Power of legislative interpretation is vested in the $\mathrm{NPCSC}^{7}$ and its interpretations have the same legal authority as national laws. ${ }^{8}$

National Administrative Regulations are issued by the State Council, promulgated by Order of the State Council, and signed by the Premier of the State Council. ${ }^{9}$ Under the Constitution, National Laws have higher legal authority than Administrative Regulations; the latter have higher legal authority than Rules. ${ }^{10}$
The power to issue judicial opinions is vested in the People's Courts. According to the Organic Law of the People's Courts of the People's Republic of China, judgments and orders issued by the SPC are legally effective and have legal authority, but the Organic Law does not explicitly state the level of legal authority in comparison with laws and administrative regulations. "I Chinese courts do not follow the principle of stare decisis. ${ }^{12}$ In practice, the SPC recently launched a series of selective cases that "have a guiding function for trial and enforcement by people's courts throughout the country".13 Although there is no official statement on what is intended to be a "guiding function", it is reasonable to expect those guiding cases to exercise great influence over lower courts. ${ }^{14}$ The judicial interpretations by the SPC have legal authority but can only address "specific issues concerning the application of law in the trial work of the courts"15 and shall not be in conflict with legislation. ${ }^{16}$

In parallel with the SPC is the Supreme People's Procuratorate of the People's Republic of China (SPP), "a state organ that is responsible for legal supervision". ${ }^{17}$ The SPP issues decisions, rules, notices, and judicial interpretations as well. Judicial interpretations issued by the SPP have legal authority and can be cited in complaints, written protests, and other legal documents. ${ }^{18}$ The SPP issued its first set of guiding cases shortly after the SPC published its first series of guiding cases. ${ }^{19}$ Both SPC and SPP are separate and independent from executive branches headed by the State Council, but are under the supervision of the NPC and NPCSC. ${ }^{20}$

There is no clear statement on the legal authority of treaties and international agreements in the Chinese legal system ${ }^{21}$ Article 67 of the Constitution stipulates that only the NPCSC is empowered to ratify or abrogate treatises and important agreements. ${ }^{22}$ The President must sign to validate the ratification. ${ }^{23}$ This requirement resembles the process of enactment of national laws that must be issued by the NPCSC and signed by the President. ${ }^{24}$ Furthermore, in practice, many laws have explicitly acknowledged the legal authority of international agreements or treaties. ${ }^{25}$

\section{B. The Legal Framework of Public Access to Primary Legal Information}

\section{Constitutional Principles and International Organisations}

Although the Constitution explicitly states that Chinese citizens ("except persons deprived of political rights according to law") have the fundamental rights to vote ${ }^{26}$ and to "criticise and make suggestions to any state organ or functionary", 27 none of these provisions or the Constitution in its entirety clearly acknowledges the right to government information as a fundamental right. One could argue, however, unfettered access to government information is not only necessary but imperative to realise both fundamental rights to vote and to criticise 
and make suggestions to any state organ or functionary, as well as the power to administer state affairs and other affairs in accordance with the law, a right guaranteed under Article 2 of the Constitution. ${ }^{28}$

Article 19 of the Universal Declaration of Human Rights ("Declaration") states that "everyone has the right to freedom of opinion and expression" which includes the "freedom to hold opinions without interference and to seek, receive and impart information and ideas through any media and regardless of frontiers". ${ }^{29}$ Despite being one of the United Nations Member States, the People's Republic of China has not yet endorsed the Declaration. However, since the General Assembly "proclaims this universal declaration of human rights as a common standard of achievements for all peoples and all nations that every individual and every organ of society.... [which] Shall... secure their universal and effective recognition and observance, both among the peoples of Member States themselves and among the peoples of territories under their jurisdiction", 30 one could argue that the People's Republic of China as a Member State has an obligation to respect, observe, or at least recognise the Declaration to be consistent with its obligation as a member of the United Nations General Assembly.

In $1998,{ }^{31}$ China signed the International Covenant on Civil and Political Rights ("Covenant"). Article 19 stipulates that "[e]veryone shall have the right to expression; this right shall include freedom to seek, receive and impart information and ideas of all kinds...".32 The 2012 White Paper on Progress in China's Human Rights explicitly states that China is working actively for "the approval of the International Covenant on Civil and Political Rights". ${ }^{33}$

China joined the WTO in 2001 after a 15-year-long negotiation. Predictability is one of the major and fundamental principles of the World Trade Organization. Predictability is realised and guaranteed through binding rules and government transparency. ${ }^{34}$ Article $X$ of the General Agreement on Tariffs and Trade ("GATT") stipulates that "[l]aws, regulations, judicial decisions and administrative rulings of general application, made effective by any contracting party... shall be published promptly in such a manner as to enable governments and traders to become acquainted with them". ${ }^{35}$ Since the public can be traders, it is reasonable to infer that the transparency obligation of the WTO requires the guarantee of public access to legal information.

China became an observer in 2002 to the WTO's Agreement on Government Procurement ("GPA"), which requires parties to "publish laws, regulations, judicial decisions, administrative rulings of general application and any procedures regarding government procurement covered by the Agreement". ${ }^{36}$ Since then, China has been taking steps towards officially becoming a party to GPA. ${ }^{37}$

Although there is no direct and explicit requirement through either the Constitution or the international treaties and agreements by which China is currently legally bound, the general principles reflected from both at least indirectly show a necessity for public access to government information including legal information. In practice, PRC's active pursuit to ratify the International Covenant on Civil and Political Rights and to join the GPA indicate the official government position on opening primary legal information to the public.

\section{Laws and Regulations on Public Access to Primary Legal Information}

A panoramic view of China's domestic legal, economic and social development in the last three or four decades shows a unique characteristic in terms of its reform process; that is, reform through experiments (试点改革). This measure is also used in the open government information arena.

Instead of passing a national law on opening government information that would cover all governmental branches on both the national and local levels, China relies on individual branches to issue their own regulations and rules governing opening government information. Furthermore, within the executive branch, as discussed above, the national State Council regulation came after multiple local governments had tried to implement public access regulations. ${ }^{38}$ Finally, instead of having a national law governing the issue, many individual laws and regulations governing specific areas of law include mandatory or voluntary disclosure of government information within their scope. ${ }^{39}$

On the other hand, many national laws restrict public access to government information and may impede public access to primary legal information as well, such as the Law of the People's Republic of China on Guarding State Secrets ("State Secrets Law"). ${ }^{40}$

\section{I Legal Instruments promoting the opening of} government information in the four branches: Congress, State Council, Judiciary and Procuratorary

\section{I.I. The National People's Congress and its Standing} Committee. Although no specific national law has been issued to open government information, there is a longstanding requirement that laws issued by the NPC must be published in official gazettes and national newspapers after being signed by the President in official gazettes and national newspapers in a timely manner. ${ }^{41}$ The version published in the Official Gazette of the Standing Committee of the National People's Congress is considered the most authoritative. ${ }^{42}$ Article 35 of the Law on Legislation allows the draft bills listed on the NPCSC's agenda to be published for public comments if approved by the Council of Chairman. ${ }^{43}$

2.1.2. The State Council and its Departments. The OGI was passed and promulgated by the State Council on April 5, 2007 and became effective on May I, 2008. Article 2 defines "government information" as 
"information produced or acquired in the process of performing duties, and recorded or kept in certain forms by administrative organs". 44 The OGI requires mandatory disclosure of four types of information 45 and clearly lists administrative regulations, rules and normative documents as a top priority on the disclosure list. ${ }^{46}$ Information falling under the categories of mandatory disclosure must be disclosed through "government gazettes, government websites, news conferences, newspapers and periodicals, broadcasting, television or any other means that are convenient for the general public to access the information".47 Disclosure must occur "within 20 working days since the day that the government information is formed or changed" or "otherwise stipulated by any law or regulation". In case of conflict, the latter provision prevails. ${ }^{48}$ Since the enactment of the OGI, hundreds of department rules, measures and other normative documents have been issued on implementing the $O G \mid$ among all the departments and units under supervision of the State Council. Beginning in 2008, departments have issued annual reports on the disclosure of government information.

\subsubsection{The Supreme People's Court and the Supreme} People's Procuratorate. According to the Administrative Measures for the Proclamation of Judicial Documents by the SPC ("Measure"), 49 the SPC selectively publishes judicial orders and verdicts through a variety of media depending on the importance of the orders or verdicts. Cases of important impact are published in the newspapers, such as the People's Daily or the Legal Daily. Representative or guiding cases will be published in the newspaper or official bulletin. Other cases are published on the court websites. Furthermore, cases are compiled and published in paper annually. The Measure is very vague and therefore is hard to implement. It does not specify a time requirement for publishing cases in newspapers, official bulletins or websites. Nor does the Measure indicate specific publisher(s) for case compilations in paper. The SPC has not revisited it since its enactment.

Instead, in 2010, the SPC issued a notice on publishing judicial documents online and live broadcasting and re-broadcasting of court trials. ${ }^{50}$ The 2010 Notice provides more lucid guidelines on timing and content that must be put on or removed from documents. More recently, the judicial committee of the SPC adopted the Provisions of the Supreme People's Court ${ }^{51}$ on the Issuance of Judgments on the internet by the People's Courts ("Provisions"), effective January I, 20|4. With the goal to "promote judicial justice and enhance judicial credibility", 52 the Provisions mandate the People's Courts to "issue judgments on the Internet under the principles of legality, timeliness, standardisation and truthfulness". 53 Article 4 lists four categories of exceptions. ${ }^{54}$ Furthermore certain information will be removed when disclosure is made under article 6 and article 7.55 In addition, the Provisions call for an "easy-to-use search and retrieve system" for the public. ${ }^{56}$ The SPP has not issued similar notices or measures yet.

In 2005, the SPC started to plan on developing a "case guidance" system. ${ }^{57}$ It was not until recent years that SPC and SPP started to issue guiding cases. ${ }^{58}$ One of the most recent SPC's guiding cases, for the very first time, addressed an issue regarding administrative processing of OGI requests. ${ }^{59}$

Meanwhile, a few national laws governing litigations in civil, criminal and administrative law areas require open court trials unless otherwise stipulated. For example, Article 120 of the Civil Procedure Law of the People's Republic of China requires all civil cases to be tried openly, except "those that involve State secrets or personal privacy or to be tried otherwise as provided by the law".60 In addition, "[A] divorce case or a case involving trade secrets may not be heard in public if a party so requests".61

Therefore, all four branches have taken steps to promote public access to government information including legal information either in practice or in principle or both. However, there is no one national law that uniformly governs the access across all four branches.

\subsection{Laws and regulations restricting access to} government information. The OGI itself restricts unlimited public access to government information in three facets: first, the burden is on the petitioner to first prove "special needs for production, living or scientific research" for disclosure of information that is not otherwise required for disclosure under articles 9-12.62 Second, disclosure of information involving state secrets, commercial secrets, or individual privacy is prohibited. Finally, administrative organs are required to establish a review system to ensure that no disclosure of information violates the National State Secrets Law or any other laws, regulations or rules. For the latter two categories, information may be disclosed if the affected party agrees and the administrative agency confirms that no important public interest is harmed through disclosure. ${ }^{63}$ Furthermore, no disclosure is allowed if it would endanger national security, public security, economic security, or social stability. 64

Similarly, all laws and regulations promoting public access to government information in specific areas generally explicitly prohibit information disclosure that will violate national state secrets law, individual privacy, or trade secrets.

The State Secrets Law defines the scope and classification of state secrets under articles 9 and 10.65 The newly amended law calls for a balance between "keeping State secrets safe" and "reasonable utilisation of information resources". ${ }^{66}$ Although right to privacy is generally recognised across all the relevant laws and regulations, there has not been a clear definition of what constitutes 
privacy or private information. Similarly, no national law clearly defines trade secrets yet. The most recent attempt to define trade secrets is through the Interim Provision of Trade Secrets of Central Enterprises issued by the State-owned Assets Supervision and Administration Commission of the State Council. ${ }^{67}$ Lack of clear definitions can certainly create obstacles for public access to government information. It may not affect public access to primary legal information as much, because primary legal information must be promulgated to the public to be effective ${ }^{68}$ and is unlikely to fall under the law's exceptions, such as privacy, state secrets, commercial secrets, etc. However, it may affect disclosure of other legal documents produced in the law-making process, such as meeting records.

\section{THE CURRENT STATUS OF PUBLIC ACCESS TO PRIMARY LEGAL INFORMATION}

There have been growing efforts to evaluate national government legal portals in China in the field of legal information and law librarianship. ${ }^{69}$ In this section, I will focus on evaluating the official legal information websites of the four major national government branches: the NPC and its standing committee, the State Council, the SPC and the SPP. The goal is to show whether the websites have allowed sufficient public access to primary legal information in China. More specifically, do the websites provide enough information or guidance so that the public will understand not only what the law is in texts but also the law in context, including the law-making process? From the usability perspective, do the websites allow the general public to search and retrieve the law easily?

\section{A. The National People's Congress}

In 2004, the National People's Congress launched its first official gateway, www.npc.gov.cn. The current interface was revamped in 2013. There are a total of 268 pages under six major categories. The website is updated daily. The website also links to the websites of local People's Congresses, Central Government agencies, and major national media. Furthermore, the website allows the public to access information (mostly news-related items) in multiple formats (texts, videos, and images) through Internet and mobile devices.

Under the Law Making subpage, there are links to three other databases/websites that are extremely helpful for the public: Draft Bills for comments, ${ }^{70}$ Legal Interpretation and $Q \& A,{ }^{71}$ and the PRC Laws and Regulations Database. ${ }^{72}$

Under the Draft Bills for Comments subpage, there are two tables: one contains draft bills that are open for public comments with full texts of the bills. In order to access the text of the bills, a user must register first and then $\log$ in. Upon accessing the database that has draft bills currently open for public comments, a user can download the draft bill as well as an official explanation of the bill as a Word document. A user can submit comments provision by provision directly online in the same interface. However, public comments submitted are not accessible to the public.

The other table lists draft bills that are already closed for public comments, with information on commenting period and basic statistical information on the number of people submitting comments and the number of comments submitted. The coverage goes back to 2005 . Although the full text of the draft bills closed for comments is not available directly through the table, for some draft bills, the full text (2008 and after $\left.{ }^{73}\right)$ is available through a link on the left side of the webpage. Text is available in html format and again public comments submitted are not accessible to the public. The commenting period for draft bills of the NPC has been consistently a month since 2005 . There is no instruction on how to request full text of draft bills or public comments that are not available on the website in full text.

The Law-Making sub-page directs users to the NPC Laws and Regulations Database. The database contains the full text of the Constitution; all laws, regulations and rules issued by the NPC including NPCSC; State Council including departments under supervision of State Council; as well as SPC's judicial interpretations starting from 1949. The database allows users to search by promulgation date, effective date, title, promulgating agency, subject, and keyword (a full text search) and is also browseable. Each document is available in full-text html with pertinent citations and effective dates; the documents are also crossreferenced to other relevant documents. Although the Database is maintained by an official government agency, it explicitly states that the information contained in the database is only for reference, and cannot be cited as an authoritative version. According to the Law on Legislation, the most authoritative version of laws and regulations issued by the NPC and its standing committee is published in the Official Gazette of the NPCSC. ${ }^{74}$ Only issue no. 6 of 2007 is available in full text in html on the NPC website. $^{75}$ The search function is not working as of March 8, 2014. The link to the Official Gazette webpage is made available on the NPC homepage, but is obsolete. International treaties are listed under the Documents subpage with about 320 international treaties and agreements available in full text. ${ }^{76}$

Under the Legislation Interpretation and $Q$ \& $A$ subpage, full texts of the NPC's interpretation of selectively important enacted national laws are available to the public in html. As of March 8, 2014, there are legislative interpretations of 10 important national laws available on the website. 77 Under the $Q$ \& A section, practical guidance on some national laws is available to the public. As no source or editor's information for each of the $Q$ \& $A$ items is provided, it is hard to identify who is the principal producer of the information and therefore it may serve for informational purposes at best. ${ }^{78}$ 
Launched in 2006, ${ }^{79}$ the English version of the NPC website $^{80}$ is much less comprehensive than its Chinese counterpart in scope. Full text of the Constitution (both current and historical versions) along with basic information on the structure and major units and committees of the NPC are available on the English version of the website. Under the Documents and Speeches sub-page, full texts of selective government work reports are available in html. The website also includes videos and images related to the NPC's work. The website links to local people's Congresses as well as other relevant government and news media websites. More importantly, the website links to the English version of the NPC's Laws and Regulations Database. ${ }^{81}$ The English interface is less comprehensive than the Chinese interface in scope, as it only contains national laws and regulations enacted by the NPC and the State Council. 82 It is searchable by very limited search functionalities: title, keyword full-text search, and year. It is browseable by eight major categories. Each document is available in full-text $\mathrm{html}$ and can be printed or emailed directly from the website, but not downloadable. Unlike the Chinese interface, NPC has no disclaimer regarding the authoritativeness of its English translations. It is probably for informative purposes only, like its Chinese counterpart.

\section{B. The State Council}

Originally launched in 2006, the official gateway of the State Council of the PRC recently released a new interface on February $28,2014 .{ }^{83}$ The ultimate goals are to promote public access to government information, strengthen public participation, and enhance public trust in government. ${ }^{84}$ These goals are consistent with the State Council's primary intent in enacting and implementing $O G \mid{ }^{85}$ Under the new interface, there are eight major sections. The State Council also created a Weibo (Microblogging; Chinese Twitter) account for the public to follow recent updates. ${ }^{86}$

Under the Policy section, the full text of laws and regulations and department rules is made available in html. The most current laws, regulations, and department rules are available by browsing, but the search engine on the left-hand side allows users to search and retrieve laws and regulations in full text back to the 1980s. The website also provides interpretations and explanations of the laws, regulations, and department rules to facilitate better public understanding. Furthermore, the website links to a subpage that contains the catalogue, guidance, and full text of all the government information that must required for disclosure under the OGl. The sub-page is searchable and browsable. More importantly, the website also links to a sub-page that contains all the State Council official gazettes in full text PDF since 1954. Users can search or browse by year. The Official Gazette of the State Council contains the most authoritative legal texts along with other key government information, according to Article 62 of the Legislation Law. ${ }^{87}$ English tables of contents for the Official Gazette, from 1999 to 2007, are also available in html.

Under the Public Service section, the webpage provides basic information targeting various audiences (general public, enterprises, foreigners, and social organisations) to facilitate public understanding of laws and government policies. More importantly, it links to websites of departments under the supervision of the State Council, where the users can search and retrieve other key information and public records such as registration, license information etc.

There is also an English interface of the official gateway of the State Council. The English interface is still the older interface that was launched in 2005. Under the Laws and Regulations section, English-language full text of major laws and regulations from 2000 to 2003 are made available to the public in $\mathrm{html} .{ }^{88}$ Under the Official Publications section, white papers, work reports, budget reports, and other key documents are made available in full text html since $2000 .{ }^{89}$

In addition to the official gateway, the State Council Legislative Affairs Office launched an official Chinese government legal information system in 2003 with 12 major categories of information. ${ }^{90}$ The website links to local government websites that are also making aggressive efforts to make laws and regulations available to the public in full text.

Under the New Laws sub-page, many laws, administrative regulations, local regulations, agency guidance and policy documents, State Council departments' rules, local government rules, international treaties and conventions, judicial interpretations, notices and guidance issued by the SPC and SPP, and selective judicial decisions from the early $2000 \mathrm{~s}$ are made available in full text $\mathrm{html}$ to the public. Furthermore, there is also a Q\&A section where explanations of recently enacted administrative regulations are provided to the public in an easy-to-read format. ${ }^{91}$

Furthermore, the sub-page links to a Laws and Regulations full text database that is maintained by the State Council Legal Affairs office. ${ }^{92}$ The database contains all laws, regulations, and departmental rules from both the central government and local governments in full-text $\mathrm{html}$, going back to the 1950s. The database can be searched by title, keyword (a full text search), promulgation agency, and date. Under the sub-page Legal Publications, information regarding secondary legal monographs and primary laws and regulations publications by China Legal Publishing House is provided. ${ }^{93}$

Under the Public Participation sub-page, notices on soliciting public comments for drafts of administrative regulations and department rules are made available to the public with instructions on how to submit comments in the newly-launched regulations and rules drafts comments database. ${ }^{94}$ The database allows users to $\log$ in and submit comments anonymously. The public comment period is generally about a month. Users can submit comments article by article. Within 
the database, cross-links to relevant documents and other laws and regulations are provided to facilitate commentators' understanding of the regulations. The full text of regulations and rules that are currently open for comments or which have recently closed for comments is available to the public, but no public comments are available.

The English interface of the website contains English summaries of laws, regulations, department rules, and judicial interpretations. ${ }^{95}$

\section{Supreme People's Court}

The Supreme People's Court recently revamped its official gateway, which was first launched in 2000.96 The website has eight major categories of information.

Under the sub-page Authoritative Promulgation, SPC judicial interpretations and notices, as well as selective judgments since 2010, are made available to the public in full-text html. The SPC also posts judicial statistics from 2008 online. The SPC makes available the Table of Contents of its official gazette since 2010 .

Under the sub-page Public Service, the SPC provides basic guidelines on litigation along with basic sample court forms. Furthermore, the SPC launched a database that allows the public to check judgment enforcement status for newly issued judgments, from 2007 onwards. ${ }^{97}$ This initiative is considered part of the efforts to tackle the notorious difficulty of enforcing judicial judgments in China. In 2009, the SPC issued a judicial interpretation on ensuring information accuracy in the database. ${ }^{98}$ Furthermore, in 2009, the SPC launched another system that allows the public to report any illegal or corrupt activities by judges. ${ }^{99}$

In addition to the official website of the SPC, the official gateway to the entire People's Court system was first launched in 2002 (revamped in $2012^{100}$ ), and is maintained by the People's Court Daily under the supervision of the SPC. ${ }^{101}$ The website provides court news, local court information, and news of recent judicial decisions, and more importantly full-text judicial decisions and court notices. ${ }^{102}$

The Judicial Opinions of China database ${ }^{103}$ allows the public to search and browse full- text judicial decisions issued by the national and local courts in html back to 1949. The database is searchable by docket number, case name, and keyword (a full-text search). It is also browseable by issuing court and by type of decisions. The Court Notice website, 104 maintained by the People's Court Daily, allows the public to search for official notices issued by the People's Courts in full-text PDF.105

In addition, the SPC launched a database that contains intellectual property rights judgments and decisions. ${ }^{106}$ The new interface was launched in 2011.107 The database allows searching by keyword in full text, docket number, court, and decision date. It is also browseable by subject. It includes decisions from both national courts and local courts, back to at least $201 \mathrm{I}$ in full-text html.
More recently, the website launched a video version $^{108}$ and a live-broadcasting trials page. ${ }^{109}$ There is an English interface of the China Court website, but it appears not to have been updated since 2009. 110

\section{Supreme People's Procuratorate}

The official website of the SPP has six major sections. It also has a sitemap. Under the Authoritative Promulgation, the Table of Contents of recent issues (2010-) of the Official Gazette of the SPP are made available. "I Pertinent laws, regulations, internal rules, and SPP judicial interpretations (2010-) are available in fulltext html. ${ }^{1 / 2}$

The Public Services sub-section links to several major databases, including the NPC's Laws and Regulations Database (link obsolete); the Legal Aid Information Management System by the Department of Justice of the State Council; '13 the Reporting Center for Crimes 114 and the Bribery Crime Conviction Information Center, which allows the public to search for information related to convictions of bribery since 1997.115 The website does not have an English interface.

\section{CONCLUSION}

The above survey shows active efforts across all four branches to provide public access to legal information and to provide platforms for public participation, even though only the State Council and the SPC have issued explicit legal instruments mandating public access to legal information. Starting in around 2000, all four branches have launched websites that include major laws and regulations in full text and platforms for public participation in the Chinese interface.

A closer look, however, shows that there is still a long way to go before the government branches fulfill the goal of providing public access to authenticated legal information.

First, there is still a lack of access to authenticated legal texts. The official gazettes are still considered the most authentic and standard version of legal texts and are generally only available in paper; only the NPC websites make recent issues of the official gazette of the NPCSC in PDF format. Furthermore, none of the websites shows information regarding who publishes the official government gazettes and where to acquire official government gazettes in paper. Some websites explicitly state that the legal information provided on the website is just for informational purposes, while others do not address the issue at all.

Second, in terms of the timeliness of legal information, all websites appear to be well- maintained and updated daily. But dates of coverage vary from the most recent two years to as early as 1949. In terms of the content, some websites and databases are clear about their coverage, but others are vague. For example, it is unclear whether the recently launched judicial opinions 
website includes all decisions issued from July I, 2013, or only selective decisions; there are no explicit statements indicating the completeness. Although the NPC Laws and Regulations database provides information regarding the effective dates of the laws and regulations in the database, the other websites and databases do not provide any information regarding the validity of the primary legal information provided. For example, there is no simple way to tell whether a trial court decision has been overruled or upheld by a higher court, unless a user can locate the higher court decision.

Third, in terms of the law-making/rule-making process, although both NPC and State Council have launched a database to allow the public to submit comments on draft bills and draft rules and regulations, the commenting period is generally very short and comments are not made available to the public. There is also no information regarding how the government has addressed the public comments and whether the government has made responsive changes to the draft bills, regulations and rules that are closed for comments.

In terms of usability of the websites, in early 2014 almost all branches have launched newer interfaces that are generally more developed than the older interfaces. For example, many websites provide multi-media access to legal information, which allows people with limited literacy and people with disabilities to better access legal information. However, the level of uniformity varies widely across all websites. Some websites have a site map that helps navigation, but others do not. Some websites have a section on legal publications, whereas others do not. As for the platforms that allow public participation, some require the general public to log in, but others do not. Some provide the contact information of the agencies maintaining the websites, whereas others do not. Some provide better search functionalities than others.

Lack of access to authenticated legal information and lack of uniformity and standards to provide more userfriendly interfaces will undoubtedly present significant obstacles to providing meaningful public access to legal information. Enactment of national legislation that mandates public access to primary legal information across all governmental branches, including the NPC and its standing committee, State Council, SPC and SPP may be part of the solution. Such a law would give the public a legal justification to request legal information that is otherwise inaccessible. "Legal information", again, is not just about primary legal texts, but also includes legal documents that help users understand the rule-making and lawmaking process. Furthermore, a national law requiring open government information could also delegate powers to government branches to issue clear guidelines to improve the usability of websites. Finally, a national law enacted by the NPC with a higher legal authority will help protect the public's interest in open government information when that interest conflicts with interests protected by other national law.

\section{Footnotes}

'The author wishes to thank Mary Rumsey of the University of Minnesota Law School for her invaluable comments and help during the preparation of this article.

${ }^{2}$ Measures on Publicising Guangzhou City Government Affairs (Trial) (Guangzhou Shi Renmin Zhengfu Gongkai Zhengwu Huodong Shixing Banfa) (1992, repealed 2002). The regulation was repealed by the Provisions of Guangzhou City on Open Governmental Information (Guongzhou Shi Renmin Zhengfu Xinxi Gongkai Guiding) (2002). Following that, about another fourteen local governments issued regulations or temporary measures on opening government information: Shenzhen City (2004), Shanghai City (2004), Chengdu City (2004), Hangzhou City (2004), Hubei Province (2004), Ningbo City (2004), Hebei Province (2005), etc.

${ }^{3}$ Regulation of the People's Republic of China on Open Government Information (Zhonghua Remin Gongheguo Zhengfu Xinxi Gongkai Tiaoli) (2007).

${ }^{4}$ Constitution of the People's Republic of China (Zhonghua Remin Gongheguo Xianfa) ("Xianfa") (1982, last amended 2004)

${ }^{5}$ Ibid. Art. 5 (English translation from the NPC Laws and Regulations Database.)

${ }^{6}$ Legislation Law of the People's Republic of China (Zhonghua Remin Gongheguo Lfofa) ("Law on Legislation"), Arts. 7 \& 23 (2000).

${ }^{7}$ Ibid. Art. 42.

${ }^{8}$ Ibid. Art. 47.

${ }^{9}$ Ibid. Arts. 56 \& 61 .

${ }^{10}$ bid. Art. 79.

" Organic Law of the People's Courts of the People's Republic of China (Zhonghua Remin Gongheguo Remin Fayuan Zuzhi Fa) (1979, last amended 2006).

12 In practice, lower courts do follow higher court, especially SPC decisions. See Albert Chen (2011), An Introduction to the legal system of the People's Republic of China, $4^{\text {th }}$ ed., LexisNexis Hong Kong, p. 167.

${ }^{13}$ Notice of the Supreme People's Court on Issuing Guidance Cases (Zuigao Remin Fayuan Guanyu Fabu Zhidaoxing Anli de Tongzhi), Art. 2 (2010). The selection criteria are legally effective cases that "attract wide attention from society," "contain legal provisions on principles of law," "are typical," "are difficult and complicated or novel," or "otherwise have guiding function". Ibid. [Translated by author] 
${ }^{14}$ For detailed discussions on China's newly developed "guiding case system" see Deng, Jinting. (2013) The guiding case system in Mainland China. Working Paper, available at http://papers.ssrn.com/sol3/papers.cfm?abstract_id=2318958; Zhang, Zhiming. Woguo Fayuan Anli Zhidao Zhidu de Quanxin Dingwei, GuangMing Daily (Shanghai, 29 June 20I I); Wang, Lifeng. (2013) The necessity and function of China's Guiding Cases, available at http://cgc.law.stanford.edu/wp-content/uploads/2013//0/CGCPEnglish-Commentary-9-Professor-Wang.pdf (last visited Mar. 10, 2014)

${ }^{15}$ Ibid. Art. 13.

${ }^{16}$ Chen, Albert. (201I) An Introduction to the legal system of the People's Republic of China. $4^{\text {th }}$ ed. Hong Kong, LexisNexis. 166

${ }^{17}$ Xianfa (n 3), Art 129. More specifically, it is empowered to "exercise procuratorial authority over treason cases," "conduct investigations on criminal cases," "review cases investigated by public security organs and determine whether to approve arrest, prosecute or exempt, as well as supervise investigatory activities of public security organs," "initiate public prosecutions on criminal cases," etc. See Organic Law of the People's Procuratorates of the People's Republic of China, arts. 2-5 (1979, last amended 2006). [English translation from the NPC Laws and Regulations Database] The People's Procuratorate also has jurisdiction over crimes of corruption, bribery, dereliction of duty and infringement. See http://www. spp.gov.cn/

${ }^{18}$ Notice of the Supreme People's Procuratorate on Publishing and Printing the Provisions of the Supreme People's Procuratorate on the Judicial Interpretation Work (Zuigao Remin Jiancha Yuan Guanyu Yinfa Zuigao Remin Jianchayuan Sifa Jieshi Gongzuo Guiding de Tongzhi), Art. 5 (2006).

${ }^{19}$ Notice of the Supreme People's Procuratorate on Publishing and Printing the First Set of Guiding Cases (Zuigao Remin Fayuan Guanyu Yinfa Diyipi Zhidaoxing Anli de Tongzhi) (2010).

${ }^{20}$ Xianfa (n 3), arts. 62, $63 \& 67$.

${ }^{21}$ Clarke, Donald C. (2003) China's Legal System and the WTO: Prospects for Compliance, Washington University Global Studies Law Review 2, 98-102.

${ }^{22}$ Xianfo (n 3), art. 67.

${ }^{23}$ Law of the People's Republic of China on the Procedure of the Conclusion of Treaties (Zhonghua Remin Gongheguo Dijie Yiaoyue Chengxu Fa), Art. 7 (1990).

24 Law on Legislation (n 5), Arts. 7 \& 41 (2000).

${ }^{25}$ For example, Article 238 of the Civil Procedure Law of the People's Republic of China states "[i]f an international treaty concluded or acceded to by the People's Republic of China contains provisions that differ from provisions of this Law, the provisions of the international treaty shall apply, except those on which China has made reservations". See Civil Procedure Law of the People's Republic of China (Zhonghuo Remin Gongheguo Minshi Susong Fa), Art. 238 (1991, last amended 2007) [English translation from the NPC Laws and Regulations Database].

${ }^{26}$ Xianfa (n 3), Art. 34.

${ }^{27}$ Xianfa (n 3), Art. 41. [English translation from NPC Laws and Regulations Database]

${ }^{28}$ See Xianfa (n 3), Art. 2. Without the right to acquire government information from authentic sources, any suggestions or criticism will not be beneficial; without the right to acquire government information from official sources, citizens will not be able to exercise their right to vote in an informed and wise manner; and without the right to acquire government information, any effort for the people to influence governmental affairs would be futile.

${ }^{29}$ Universal Declaration of Human Rights, G.A. Res. 217 (III) A, U.N. Doc. A/Res/217 (III), Art. 19 (Dec. 10, 1948).

${ }^{30}$ See Declaration (n 28) Preamble.

${ }^{31}$ See https://treaties.un.org/Pages/NiewDetails.aspx?src=TREATY\&mtdsg_no=IV-4\&chapter=4\&lang=en\#4

${ }^{32}$ International Covenant on Civil and Political Rights, G.A. Res. 2200A(XXI), 999 U.N.T.S. I7I (Mar. 23, 1976).

${ }^{33}$ See State Council Information Office (2013), White Paper: Progress in China's Human Rights in 2012, available at http://www. china.org.cn/chinese/2013-05/14/content_28819357_8.htm (last visited Mar. 20, 2014).

${ }^{34}$ World Trade Organization (20II) Understanding the WTO: Basics, $5^{\text {th }}$ ed. Geneva, World Trade Organization. 10-13.

${ }^{35}$ General Agreement on Tariffs and Trade, 61 Stat. A-II, 55 U.N.T.S. 194, art. X (Oct. 30, 1947).

${ }^{36}$ Agreement on Government Procurement, 1867 U.N.T.S. III (Apr. 15, 1994).

${ }^{37}$ Demetrios Marantis (n.d.) The WTO Government Procedure Agreement: Tremendous opportunity of China, available at http:// shenyang.usembassy-china.org.cn/wto-gpa.html (last accessed Mar. 10, 2014).

${ }^{38}$ See Introduction.

${ }^{39}$ For example, Article 82 of the Food Safety Law of the People's Republic of China mandates a uniform system of releasing food safety information to the public.

${ }^{40}$ Law of the People's Republic of China on Guarding State Secrets (Zhonghuo Remin Gongheguo Baohu Guojia Mimi Fa) (2010)

${ }^{41}$ Low on Legislation (n 5), Art. 52.

${ }^{42}$ NPCSC Legal Affairs Working Committee, Zhongthua Renmin Guoheguo Lifofa Shiyi (2000)

${ }^{43}$ Low on Legislation ( 5 ), Art. 35.

${ }^{44}$ OGI (n 2), Art. 2 [translated by author] 
${ }^{45}$ Ibid. Art. 9.

${ }^{46} \mathrm{lbid}$. Art. 10.

${ }^{47}$ Ibid. Art. 15.

${ }^{48}$ Ibid. Art. 18.

${ }^{49}$ Administrative Measures for the Proclamation of Judicial Documents by the Supreme People's Court (Zuigao Remin Fayuan Caipan Wenshu Gongbu Guanli Banfa) (2000).

${ }^{50}$ Provisions of the Supreme People's Court on the Issuance of Judicial Documents on the Internet by People's Courts and Provisions on the Live Broadcasting and Re-broadcasting of Court Trials by the People's Courts (Zuigao Remin Fayuan Guanyu Remin Fayuan zai Hulianwang Gongbu Caipan Wenshu de Jueding ji Zuigao Remin Fayuan Guanyu Remin Fayuan Zhibo he Congbo Tingshen de Jueding) (2010).

${ }^{51}$ Provisions of the Supreme People's Court on the Issuance of Judgments on the Internet by the People's Courts (Zuigao Remin Fayuan Guanyu Remin Fayuan zai Hulianwang Gongbu Caipan Wenshu de Jueding) (2013).

52 Ibid. Preamble [translated by author].

53 Ibid. Art. 1

54 ibid. Art. 4

55 Ibid. Arts. $6 \& 7$

${ }^{56} \mathrm{Ibid}$. Art. 12 [translated by author].

${ }^{57}$ Notice of the Supreme People's Court on Promulgating the Second Five-Year Reform Plan (2004-2008) (Zuigao Remin Fayuan Guanyu Yinfa Dierge Wunian Gaige Gangyao de Tongzhi) (2005)

${ }^{58}$ Notice of the Supreme People's Court on Issuing the First Set of Guiding Cases (Zuigao Remin Fayuan Guanyu Fabu Diyipi Zhidaoxing Anli de Tongzhi) (2011); Notice of the Supreme People's Procuratorate on Issuing the First Set of Guiding Cases (Zuigao Remin JianchaYuan Guanyu Fabu Diyibi Zhidaoxing Anli de Tongzhi) (2010).

${ }^{59} \mathrm{Li}$ jianXiong v. Guangdong Province Ministry of Transportation on Open Government Information [2014], SPC Guiding Case No. 26. Similar to US government agencies following Freedom of Information Act of the U.S., many governmental agencies in China, in accordance with the OGl, allows the public to submit their request for release of government information through different channels. Some allow submissions through an online database or information network. In this case, the plaintiff submitted his request through an online government public information network on June I, 201I. The system acknowledged successful submission of the request on the same day. According to article 24 of the OGI, for information that government cannot provide immediately, the government shall respond to the OGI request within 15 business days of a receipt of the OGI request. In this case, the court held that the system acknowledgment of successful submission is sufficient to be counted as the receiving day.

${ }^{60}$ Civil Procedure Law of the People's Republic of China (Zhonghuo Remin Gongheguo Minshi Susong Fa), Art. 134 (I991, last amended 2012) [English translation from the NPC Laws and Regulations Database]; Criminal Procedure Law of the People's Republic of China (Zhonghua Remin Gongheguo Xingshi Susong Fa), Art. 183 (1979, last amended 2013); Administrative Litigation Law of the People's Republic of China (Zhonghua Remin Gongheguo Xingzheng Susong Fa), Art. 145 (1989).

${ }^{61}$ Civil Procedure Law of the People's Republic of China (Zhonghua Remin Gongheguo Minshi Susong Fa), Art. 134 (1991, last amended 2012) [English translation from the NPC Laws and Regulations Database].

${ }^{62}$ OGI (n 2), Art. 13.

${ }^{63}$ Ibid. Art. 14.

${ }^{64}$ Ibid. Art. 8.

${ }^{65}$ State Secrets Low (n 4I), Arts. 9 \& 10.

${ }^{66}$ Ibid. Art. 4 [translated by author].

${ }^{67}$ Circular of the State-owned Assets Supervision and Administration Commission of the State Council on Printing and Issuing the Interim Provisions on Protection of Trade Secrets of Central Enterprise (Guwuyuan Guoyou ZiChan Jiandu Guanli Weiyuanhui Guanyu Yinfa <Zhongyang Qiye Shangye Mimi Baohu Zanxing Guiding> de Tongzhi) (2010)

${ }^{68}$ For example, Low on Legislation (n 5), Art. 52.

${ }^{69}$ For example, see Sha, Zhenjiang. (2004) Discussion on the evaluation standard of the law website. Journal of Information 23 , 10-II; Jiang, Jun. (2012) Lifa Jiguan FaLv Wangzhan de Shizheng Fenxi he Bijiao Fenx. Information and Research of Legal Literature 3, 7-23; Yan, Guangyong. (2013) Woguo Falv Wangzhan Bijiao Fenxi. Information and Research of Legal Literature I, I-3; Zhao, Xiaohai, He, YuanQiong \& Guo, Ye. (2013) Lun Falv Xinxi Gongkai yu Falv Wangzhan, Information and Research of Legal Literature 4, 4-12; Liu, Lijun \& Yu, Liying. (2013) Shuzihua he Chuantong Beijing zhong de Caipan Wenshu Gongkai Jizhi, FaXue 8, 59-67.

${ }^{70}$ http://www.npc.gov.cn/npc/flcazqyj/node_8176.htm.

${ }^{71}$ http://www.npc.gov.cn/npc/flsyywd/node_I793.htm.

72 http://law.npc.gov.cn/home/begin l.cbs.

${ }^{73} \mathrm{http}: / /$ www.npc.gov.cn/npe/flcazqyj/2008-04/22/content_1464905.htm.

${ }^{74}$ Low on Legislation (n 5), Art. 52. 
${ }^{75}$ http://www.npc.gov.cn/wxzl/gongbao/node_4508.htm.

${ }^{76} \mathrm{http} / / \mathrm{www} . \mathrm{npc}$. gov.cn/npc/xinwen/newwxzl.htm.

${ }^{77}$ http://www.npc.gov.cn/npc/flsyywd/node_1793.htm.

${ }^{78}$ http://www.npe.gov.cn/npc/flsyywd/flwd/node_1859.htm.

${ }^{79} \mathrm{http}: / / \mathrm{ww}$.npc.gov.cn/englishnpc/iframe/about_us.htm.

${ }^{80}$ http://www.npc.gov.cn/englishnpc/news/index.htm.

${ }^{81}$ http://www.npc.gov.cn/englishnpc/Law/Integrated_index.html.

${ }^{82}$ http://www.npc.gov.cn/englishnpc/Law/Integrated_index.html.

${ }^{83} \mathrm{http}: / / \mathrm{www} . \mathrm{gov} . \mathrm{cn} / \mathrm{xinwen} / 20 \mathrm{l}$-03/0I/content_2626102.htm.

${ }^{84} \mathrm{http}: / /$ www.gov.cn/xinwen/2014-03/01/content_2626102.htm.

${ }^{85}$ OGI (n 2), Art 1.

${ }^{86} \mathrm{http}: / /$ www.gov.cn/foot/2014-02/18/content_2611908.htm.

${ }^{87}$ Law on Legislation (n 2), Art. 62.

${ }^{88} \mathrm{http}: / /$ english.gov.cn/laws/laws.htm.

${ }^{89}$ http://english.gov.cn/official/official.htm.

${ }^{90}$ http://www.whfzb.gov.cn/site/publish/whfzb/Cl 201 I 1027 I $420300045 . s h t m l$.

${ }^{91}$ http://www.chinalaw.gov.cn/article/fgkd/xfgwd/index.shtml.

${ }^{92} \mathrm{http}: / /$ search.chinalaw.gov.cn/search $2 . h t m l$.

${ }^{93}$ http://www.chinalaw.gov.cn/article/fzts/.

${ }^{94}$ Notice of the State Council Legal Affair Office on Solicitation of Public Comments on China Legal Information Network (Guowuyuan Fazhiban jiu Zhongguo Falv Xinxiwang Gongkai Zhengqiu Yijian de Tongzhi) (2011).

${ }^{95} \mathrm{http}: / /$ www.chinalaw.gov.cn/article/english/.

${ }^{96}$ http://www.court.gov.cn/gywm/.

${ }^{97}$ http://zhixing.court.gov.cn/search/

${ }^{98}$ Several Provisions of the Supreme People's Court on the Handling of Objections to Information on the National Court Information Inquiry Platform of Persons Subject to Enforcement (Zuigao Remin Fayuan Guanyu Quanguo Fayuan Bei ZhixingRen Xinxi Chaxun Pingtan Xinxi Yiyi Chuli de Rougan Guiding) (2009).

${ }^{99}$ http://jubao.court.gov.cn.

${ }^{100}$ http://www.chinacourt.org/article/detail/20/2/03/id/473806.shtml.

101 http://www.chinacourtorg/index.shtml.

${ }^{102}$ Court Notices (Fayuan GongGao) include notices served on individuals or issued to the public by the people's courts in relation to court proceedings. According to the 2005 Notice of the Supreme People's Court on Further Providing Uniformity of Promulgations of Court Public Announcements, all public notices related to the court litigations, issued by the people's court must and can only be published on People's Court Daily, the official newspaper of the Supreme People's Court.

${ }^{103}$ http://www.court.gov.cn/zgcpwsw/.

104 http://www.rmfygg.com.

105 Notice of the Supreme People's Court on Further Standardising of Promulgations of Court Notices (Zuigao Remin Foyuan Guanyu Jinyibu Guifan Fayuan Gonggao Fabu de Tongzhi) (2005).

${ }^{106}$ http://ipr.court.gov.cn/.

107 http://old.chinacourt.org/public/detail.php?id=448893.

${ }^{108}$ http://tv.chinacourt.org.

${ }^{109}$ http://ts.chinacourt.org.

${ }^{110} \mathrm{http}: / /$ en.chinacourt.org.

III http://www.spp.gov.cn/gigb/.

112 http://www.spp.gov.cn/flfg/.

113 http://218.94.1.173.

114 It refers to crimes relating to corruption, bribery, and embezzlement that are within SPP's jurisdiction in accordance with the Article 18.2 of the Criminal Procedure Law of the People's Republic of China. See http://www.12309.gov.cn.

115 http://www.yfw.com.cn/xhfzdacx/.

\section{Biography}

Xiaomeng Zhang is a Reference and Foreign and Comparative Law Librarian at the University of Michigan Law School. She graduated from University of Kansas Law School with a J.D. degree and University of Michigan School of Information with a M.S.I degree. She is licensed to practise in the State of New York, U.S.A. 